\begin{tabular}{|c|c|c|c|c|c|c|}
\hline \multirow{4}{*}{ Impact Factor: } & ISRA (India) & $=3.117$ & SIS (USA) & $=0.912$ & ICV (Poland) & $=6.630$ \\
\hline & ISI (Dubai, UAE & $=0.829$ & РИНЦ (Russia & $=0.156$ & PIF (India) & $=1.940$ \\
\hline & GIF (Australia) & $=0.564$ & ESJI (KZ) & $=\mathbf{5 . 0 1 5}$ & IBI (India) & $=4.260$ \\
\hline & JIF & $=1.500$ & SJIF (Morocco & $=5.667$ & & \\
\hline
\end{tabular}

\section{SOI: $1.1 /$ TAS $\quad$ DOI: $10.15863 /$ TAS International Scientific Journal Theoretical \& Applied Science}

p-ISSN: 2308-4944 (print) e-ISSN: 2409-0085 (online)

Year: $2018 \quad$ Issue: 12 Volume: 68

Published: 01.12.2018 $\quad$ http://T-Science.org

SECTION 2. Applied mathematics.

Mathematical modeling.
QR - Issue

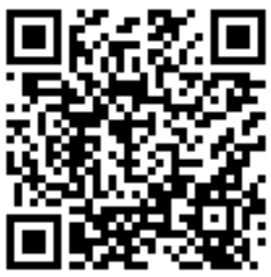

Taraz State University named after M.Kh. Dulati

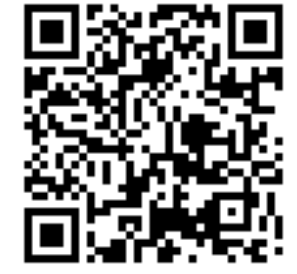

Meruyet Murat master student,

Alexandr Shevtsov candidate of technical sciences, member of PILA (USA), department of «Mathematics», deputy director on Science of faculty of Information technologies, automation and telecommunications,

Taraz State University named after M.Kh. Dulati

\title{
ON SOME NUMERICAL OPTIMIZATION ALGORITHMS
}

Abstract: The article deals with the algorithms for the implementation of optimization problems in the system of computer algebra Maple.

Key words: Delphi, Maple, equation, library.

Language: English

Citation: Murat, M., \& Shevtsov, A. (2018). On some numerical optimization algorithms. ISJ Theoretical \& Applied Science, 12 (68), 1-5.

Soi: $\underline{\text { htp://s-o-i.org/1.1/TAS-12-68-1 Doi: crossef https://dx.doi.org/10.15863/TAS.2018.12.68.1 }}$

\section{Introduction}

Any numerical method for solving the optimization problem is based on an accurate or approximate calculation of its characteristics (the value of the objective function, the functions that specify the allowable set, as well as their derivatives) [1-8]. Based on these calculations, an approximation to the solution of the problem $x$ is constructed or, if required, an approximation to the minimum value of the objective function $f$ is constructed [9-11].

Algorithms that use only information about the values of the minimized function are called zero-order algorithms. Algorithms that also use information about the values of the first derivatives-algorithms of the first order [12]; algorithms that use information about the second derivatives - algorithms of the second order.

Let us consider the process of implementation of the optimization algorithm in the system of computer algebra Maple.

\section{Materials and Methods}

The algorithm consists of two stages:

1. The calculations provided by the algorithm of the problem characteristics are performed.

2. Based on the information received at the first stage, an approximation to the solution is built.
To set the algorithm, it is enough to specify the method of setting the calculation points.

If all points are selected at the same time before the calculation starts, the minimization algorithm is called passive.

However, to solve most problems, the calculation points are chosen in turn, that is, the point $x^{i-1}$ is selected, when the points of the previous calculations $x^{0}, x^{1}, x^{2}, \ldots, x^{i}$ are already selected and the calculations provided by the algorithm are performed in each of them. Such algorithms are called sequential.

In practice, usually sequential algorithms for selecting the point of the next calculation depend only on the point of the previous calculation or on the point of the previous calculation and the linear combination of all the results.

As a result of the algorithm operation, a sequence of $x^{k}, k=1,2,3, \ldots$ points is generated.

The work of the algorithm to build each subsequent point is called an iteration (step) method, and the algorithm for constructing a sequence of points in General is called an iterative process. 


\begin{tabular}{|c|c|c|c|c|c|c|}
\hline \multirow{4}{*}{ Impact Factor: } & ISRA (India) & $=3.117$ & SIS (USA) & $=0.912$ & ICV (Poland) & $=6.630$ \\
\hline & ISI (Dubai, UAE & $=0.829$ & РИНЦ (Russia & $=\mathbf{0 . 1 5 6}$ & PIF (India) & $=1.940$ \\
\hline & GIF (Australia) & $=0.564$ & ESJI (KZ) & $=5.015$ & IBI (India) & $=4.260$ \\
\hline & JIF & $=1.500$ & SJIF (Morocco & $=5.667$ & & \\
\hline
\end{tabular}

Among the minimization methods, we can conditionally distinguish finite-step and infinite-step methods [4-12].

Finite-step methods are methods that guarantee the solution of the problem in a finite number of steps (for example, the simplex method).

Infinite-step methods generate a sequence of points, and the solution is achieved in the limit.

The numerical method implementing iterative process $x^{1}, x^{2}, x^{3}, \ldots, x^{k}, \ldots$ is generally represented by the following scheme:

1. The initial approximation is

$x^{0} \in X$

2. It is found from the solution of some auxiliary problem determined by the method, vectors $h^{k}$ and numbers $a_{k}$ on the basis of available information.

3. Element is built

$x^{k+1}=x^{k}+a_{k} h^{k}, k=0,1,2,3, \ldots$

4. The problem of stopping the iterative process is solved.

In descent methods, the direction of $h^{k}$ to the minimum at each $k$ step is chosen from the set of all decreasing directions of the function $f(x)$ at the point $x^{k}$

$$
h^{k} \in U \quad x^{k}, f, \quad k=0,1,2,3, \ldots
$$

The method is called the descent method if $h^{k}$ sets the decreasing direction of the function $f(x)$ at point $x^{k}$ (executed (3)), and the number $a_{k}$ is positive and such that

$$
f\left(x^{k-1}\right)<f\left(x^{k}\right), \quad k=0,1,2,3, \ldots
$$

The coefficients $a_{k}$ in the method can be determined from the condition

$$
f\left(x+a_{k} h^{k}\right)=\min _{a} f\left(x^{k}+a h^{k}\right),
$$

where for descent methods the minimum is $a \geq 0$. This method of choosing $a_{k}$ is in some sense the best, since it provides the least value of the function along the given direction $h^{k}$. So in this case, at each step there is a need to solve the problem of onedimensional minimization.

According to the Weierstrass approximation theorem, if a function is continuous in a certain interval, then it can be approximated with any degree of accuracy by a polynomial of sufficiently high order. Therefore, if the function is unimodal and is found by a polynomial that approximates it fairly accurately, the coordinate of the function's optimum point can be estimated by calculating the coordinate of the polynomial's optimum point. According to the
Weierstrass theorem, the quality of estimates of the coordinate of an optimum point obtained by an approximating polynomial can be improved in two ways:

1) using a higher order polynomial ;

2) decrease of the approximation interval. The second method is more preferable, since the construction of an approximating polynomial of order above the third one becomes a very complex procedure, whereas the reduction of the interval under the conditions when the assumption of the unimodality of the function is fulfilled is not particularly difficult.

The process of finding the minimum function can be divided into three stages.

1. The choice of the initial interval of uncertainty. The boundaries $\left[a_{0}, b_{0}\right]$ of the interval must be such that the function $f(x)$ is unimodal.

2. Reducing the uncertainty interval.

3. Check completion conditions. The search ends when:

* the length of the current uncertainty interval $\left[a_{k}, b_{k}\right]$ is less than the set value;

* the relative change in the value of the function $f\left(x_{k}\right)$ and $f\left(x_{k+1}\right)$ (or its derivative) becomes less than the specified value;

* the relative change in the $x_{k}$ and $x_{k+1}$ coordinates becomes less than the specified value;

* the relative change in the value of the function $f\left(x_{k}\right)$ and $f\left(x_{k+1}\right)$ (or its derivative) and the relative change in the coordinate $x_{k}$ and $x_{k+1}$ simultaneously becomes less than the specified value.

In some methods, the maximum number of function calculations is predetermined.

There are two ways to select the points at which the function values are calculated. If points are set in advance, before the calculation starts, this is a passive way to select points. If the points are selected sequentially in the search process based on the results of previous calculations, this is a sequential method.

\section{Of the boundaries of the interval}

When implementing almost all numerical algorithms of one-dimensional optimization at the initial stage, it is necessary to find a relatively wide interval containing the optimum point. Typically, the search for boundary points of this interval is carried out using heuristic search methods, although in some cases you can also use extrapolation methods.

For the heuristic choice of the initial uncertainty interval, the Sven algorithm can be applied:

1. To arbitrarily specify the following parameters: $x_{0}$ is some point, then $\Delta>0$ is the step size. Put $k=0$.

2. Calculate the value of the function at three points: $x_{0}-\Delta, x_{0}, x_{0}+\Delta$. 


\begin{tabular}{|c|c|c|c|c|c|c|}
\hline \multirow{4}{*}{ Impact Factor: } & ISRA (India) & $=\mathbf{3 . 1 1 7}$ & SIS (USA) & $=0.912$ & ICV (Poland) & $=6.630$ \\
\hline & ISI (Dubai, UAE & $=0.829$ & РИНЦ (Russia & $=0.156$ & PIF (India) & $=1.940$ \\
\hline & GIF (Australia) & $=0.564$ & ESJI (KZ) & $=5.015$ & IBI (India) & $=4.260$ \\
\hline & JIF & $=1.500$ & SJIF (Morocco & $=5.667$ & & \\
\hline
\end{tabular}

3. Check end condition:

a) if $f\left(x_{0}-\Delta\right) \geq f\left(x_{0}\right) \leq f\left(x_{0}+\Delta\right)$, then the initial interval uncertainties found: $\left[a_{0}, b_{0}\right]=\left[x_{0}-\Delta, x_{0}+\Delta\right]$;

b) if $f\left(x_{0}-\Delta\right) \leq f\left(x_{0}\right) \geq f\left(x_{0}+\Delta\right)$, then the function is not unimodal and the required uncertainty interval cannot be found. This stops the Calculation. It is recommended to set a different starting point;

C) if the end condition is not met, proceed to step 4.

4. To determine the sign of $\Delta$ :

a) if $f\left(x_{0}-\Delta\right) \geq f\left(x_{0}\right) \geq f\left(x_{0}+\Delta\right)$, then $\Delta=+\Delta, a_{0}=x_{0}, x_{1}=x_{0}+\Delta, k=1$;

b) if $f\left(x_{0}-\Delta\right) \leq f\left(x_{0}\right) \leq f\left(x_{0}+\Delta\right)$, then $\Delta=-\Delta, b_{0}=x_{0}, x_{1}=x_{0}-\Delta, k=1$,

5. To find the next point $x_{k+1}=x_{k}+2^{k} \cdot \Delta, k=0,1,2$.

6. Check condition of decreasing function :

a) if $f\left(x_{k+1}\right)<f\left(x_{k}\right)$ and $\Delta=+\Delta$, then $a_{0}=x_{k}$;

if $f\left(x_{k+1}\right)>f\left(x_{k}\right)$ and $\Delta=-\Delta$, then $b_{0}=x_{k}$.

In both cases, put $k=k+1$ and go to step 5 ;

b) if $f\left(x_{k+1}\right)>f\left(x_{k}\right)$, the search procedure is completed. When $\Delta=+\Delta$ put $b_{0}=x_{k+1}$, and when $\Delta=-\Delta$ put $a_{0}=x_{k+1}$. As a result $\left[a_{0}, b_{0}\right]-$ the required initial uncertainty interval.

Example 1. Set the initial limits of the uncertainty interval ( using Sven's heuristic method) for the function $f(x)=(100-x)^{2}$ at a given starting point $x_{0}=30$ and the step value $|\Delta|=5$.

\section{Action sequence}

1. Determination of the sign of the step $\Delta$ :

$f\left(x_{0}\right)=f(30)=4900$,

$f\left(x_{0}+|\Delta|\right)=f(35)=4225$,

$f\left(x_{0}-|\Delta|\right)=f(45)=5625$.

Since $f\left(x_{0}-|\Delta|\right) \geq f\left(x_{0}\right) \geq f\left(x_{0}+|\Delta|\right), \quad$ the value of $\Delta$ should be positive, and the coordinate of the minimum point $x^{*}$-should be greater than 30 .

2. Iterative procedure.

$$
\text { Step } 1 . \quad x_{1}=x_{0}+\Delta=35 \text {, }
$$

$f\left(x_{1}\right)=4225<f\left(x_{0}\right)=4900$. Hence, $x^{*}>30$.

$$
\text { Step 2. } x_{2}=x_{0}+2 \Delta=45 \text {, }
$$

$f\left(x_{2}\right)=3025<f\left(x_{1}\right)=4225$. Hence, $x^{*}>35$.

$$
\text { Step 3. } \quad x_{3}=x_{0}+2^{2} \Delta=65 \text {, }
$$

$f\left(x_{3}\right)=1225<f\left(x_{2}\right)=3025$. Hence, $x^{*}>45$.

$$
\text { Step 4. } \quad x_{4}=x_{0}+2^{3} \Delta=105 \text {, }
$$
$f\left(x_{4}\right)=105<f\left(x_{3}\right)=1225$. Hence, $x^{*}>65$.

$$
\text { Step 5. } x_{5}=x_{0}+2^{4} \Delta=185 \text {, }
$$

$f\left(x_{5}\right)=7225<f\left(x_{4}\right)=105$ Hence, $x^{*}>185$.

The boundaries of the initial uncertainty interval of the function $f(x)[a, b]=[65,185]$.

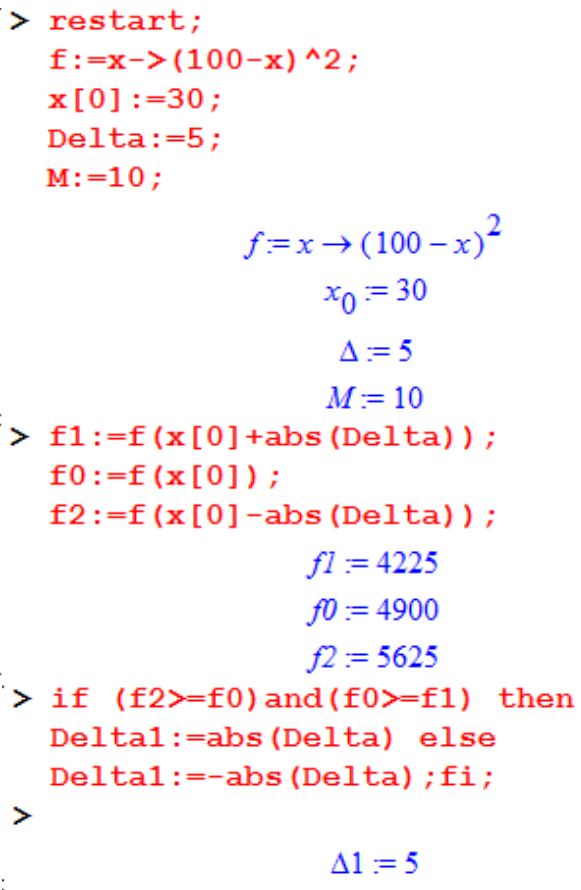




\begin{tabular}{|c|c|c|c|c|c|c|}
\hline \multirow{4}{*}{ Impact Factor: } & ISRA (India) & $=\mathbf{3 . 1 1 7}$ & SIS (USA) & $=0.912$ & ICV (Poland) & $=6.630$ \\
\hline & ISI (Dubai, UAE & $=0.829$ & РИНЦ (Russia & $=0.156$ & PIF (India) & $=1.940$ \\
\hline & GIF (Australia) & $=0.564$ & ESJI (KZ) & $=5.015$ & IBI (India) & $=4.260$ \\
\hline & JIF & $=1.500$ & SJIF (Morocco & $=5.667$ & & \\
\hline
\end{tabular}

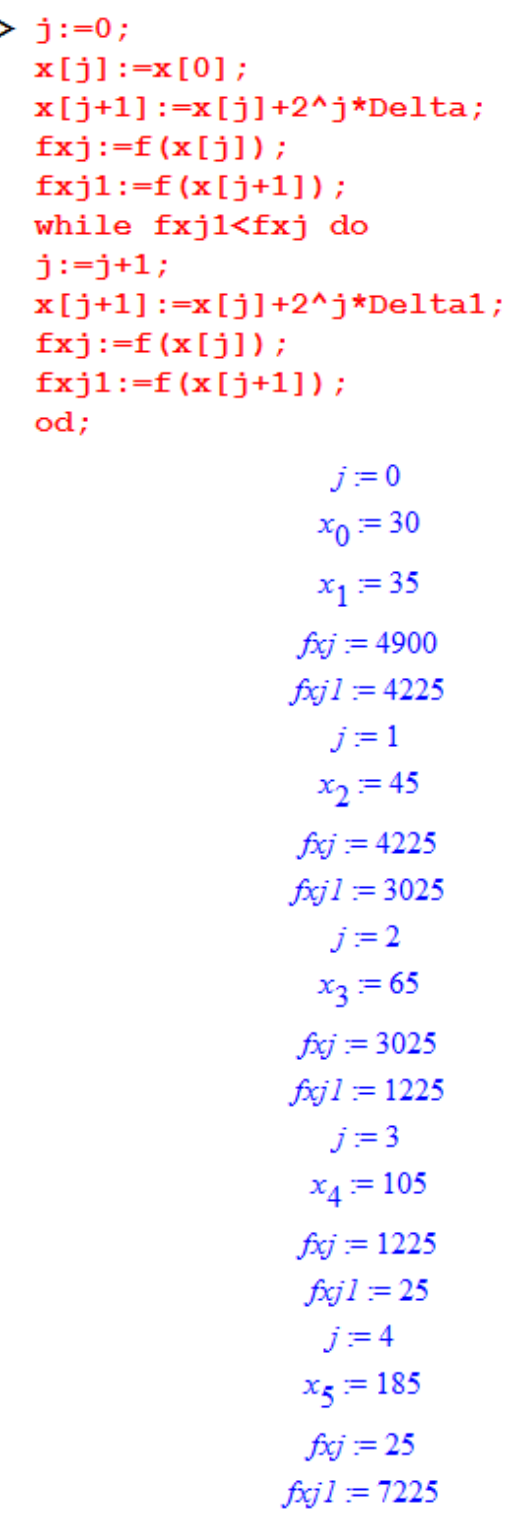

\section{Conclusion}

The result of the implementation of the algorithm for finding the uncertainty interval.

$x^{T}=(30,35,45,65,105,185)$ - coordinates of iterative points.

$$
f^{T}=(4900,4225,3025,1225,25,7225)-\text { the }
$$

function value at iteration points.
These algorithms of Maple, allow us to determine the boundary of the uncertainty interval.

The boundaries $[a, b]$ of the uncertainty interval and the values of the functions $f(a, b)$ at these points,

$[a, b]=(65,185)$ - coordinates of points of the interval, $f(a, b)=(1225,7225)$ - the function values at the points of the interval.

\section{References:}

1. Serikbaev, N., \& Shevtsov A. (2018). The development of a library of delphi for the solution of transcendental equations. ISJ
Theoretical \& Applied Science, USA, 05 (61), 110. Doi: https://dx.doi.org/10.15863/TAS.2018.05.61.1 


\begin{tabular}{|c|c|c|c|c|c|c|}
\hline \multirow{4}{*}{ Impact Factor: } & ISRA (India) & $=3.117$ & SIS (USA) & $=0.912$ & ICV (Poland) & $=6.630$ \\
\hline & ISI (Dubai, UAE & $=0.829$ & РИНЦ (Russia) & $=0.156$ & PIF (India) & $=1.940$ \\
\hline & GIF (Australia) & $=0.564$ & ESJI (KZ) & $=\mathbf{5 . 0 1 5}$ & IBI (India) & $=4.260$ \\
\hline & JIF & $=1.500$ & SJIF (Morocco) & $=5.667$ & & \\
\hline
\end{tabular}

2. Zhunisbekov, S., Shevtsov, A., \& Karymsakov, N. (2018). Development of the simplest perceptron for artificial intelligence. ISJ Theoretical \& Applied Science, 06 (62), 1-10. Soi: http://s-o-i.org/1.1/TAS-06-62-1 Doi: https://dx.doi.org/10.15863/TAS.2018.06.62.1

3. Kudryavtseva, I. V., Rykov, S., Rykov, S. V., \& Skobov, E. D. (2014). Optimization methods in the examples in the MathCAD 15 package. Part I:Studies'. manual. (p.166). SPb.: NRU ITMO, Aibt.

4. Shevtsov, A. N., et al. (2017). Innovative machines for post-harvest grain handling. ISJ Theoretical \& Applied Science, 01 (45), 171175. Soi: http://s-o-i.org/1.1/TAS-01-45-32 Doi:

https://dx.doi.org/10.15863/TAS.2017.01.45.32

5. Shevtsov, A., \& Talaybekkyzy, N. (2017). Development of autonomous robot for radiation reconnaissance. ISJ Theoretical \& Applied Science, 03 (47), 1-4. Soi: http://s-oi.org/1.1/TAS-03-47-1 Doi: https://dx.doi.org/10.15863/TAS.2017.03.47.1

6. Abenov, U., \& Shevtsov, A. (2017). The application of system maple and delphi to solve problems of discrete mathematics. ISJ Theoretical \& Applied Science, 05 (49), 101119. Soi: http://s-o-i.org/1.1/TAS-05-49-17 Doi:

https://dx.doi.org/10.15863/TAS.2017.05.49.17

7. Abenov, U., \& Shevtsov, A. (2017). The practical aspect of using greedy algorithm. ISJ Theoretical \& Applied Science, 05 (49), 120-
127. Soi: http://s-o-i.org/1.1/TAS-05-49-18 Doi:

https://dx.doi.org/10.15863/TAS.2017.05.49.18

8. Shevtsov, A., et al. (2017). Normalization of freshly harvested grain. ISJ Theoretical \& Applied Science, 05 (49), 249-256. Soi: http://so-i.org/1.1/TAS-05-49-40 Doi: https://dx.doi.org/10.15863/TAS.2017.05.49.40

9. Shevtsov, A. (2017). Development of an automatic dust collection system in mines. ISJ Theoretical \& Applied Science, 08 (52): 1-4. Soi: http://s-o-i.org/1.1/TAS-08-52-1

Doi: https://dx.doi.org/10.15863/TAS.2017.08.52.1

10. Zhunisbekov, S., Shevtsov, A., \& Kairliyeva, D. (2017). On some aspects of the implementation of the principle of hamilton in maple. ISJ Theoretical \& Applied Science, 09 (53), 89-92. Soi: http://s-o-i.org/1.1/TAS-09-53-15 Doi: https://dx.doi.org/10.15863/TAS.2017.09.53.15

11. Koybakov, S., Maliktayuly, M., \& Shevtsov, A. (2017). Simulation models of chaotic flow. ISJ Theoretical \& Applied Science, 12 (56), 87-92. Soi: http://s-o-i.org/1.1/TAS-12-56-16 Doi: https://dx.doi.org/10.15863/TAS.2017.12.56.16

12. Serikbaev, N., \& Shevtsov, A. (2017) the development of a library of maple for the solution of transcendental equations. ISJ Theoretical \& Applied Science, 12 (56), 261279. Soi: http://s-o-i.org/1.1/TAS-12-56-42 Doi: https://dx.doi.org/10.15863/TAS.2017.12.56.42 